Sri Lanka J. Aquat. Sci. 21 (2) (2016): 77-94

\title{
Water quality of Nilwala River, Sri Lanka in relation to land use practices
}

\author{
J.M.C.K. JAYAWARDANA ${ }^{1 *}$, T.R. JAYATHUNGA ${ }^{1}$ and E.A. \\ EDIRISINGHE ${ }^{2}$
}

\author{
${ }^{1}$ Department of Natural Resources, Faculty of Applied Sciences, \\ Sabaragamuwa University of Sri Lanka, Belihuloya 70140, Sri Lanka \\ ${ }^{2}$ Regional Support Center, National Water Supply and Drainage Board, \\ Pamburana,Matara 81000, Sri Lanka. \\ * Corresponding author (jayawardanack@yahoo.com)
}

\begin{abstract}
The Nilwala River is the third largest in the southern province of Sri Lanka which runs through $72 \mathrm{~km}$ along its cause. Conversion of forest lands to agricultural lands, expansion of urban areas and clearing of land for construction purposes in the catchment are major issues affecting water quality in Nilwala River. The water quality of the Nilwala River lower basin at 16 locations was estimated for 4 months from September2010 to December 2010 in two-week intervals. Water quality parameters pH, Electrical conductivity(EC), Dissolved oxygen (DO), Biochemical Oxygen demand $\left(\mathrm{BOD}_{5}\right)$, turbidity, colour, Total Dissolved Solids (TDS), total hardness, alkalinity, Nitrite- $\mathrm{N}\left(\mathrm{NO}_{2}^{-}-\mathrm{N}\right)$, Nitrate $-\mathrm{N}\left(\mathrm{NO}_{3}{ }^{-}-\mathrm{N}\right)$, Phosphate $\left(\mathrm{PO}_{4}{ }^{3-}-\mathrm{P}\right)$, Sulphate $\left(\mathrm{SO}_{4}{ }^{3-}\right)$, Total $\mathrm{Fe}, \mathrm{Ca}^{2+}, \mathrm{F}^{-}$and $\mathrm{Cl}^{-}$were evaluated in the sampling locations. The spatial and temporal variation of water quality associated with different land use categories were analyzed using Two-way ANOVA. Principal Component Analysis (PCA) and Cluster Analysis (CA) were also conducted to determine the association between water quality variation and land use impacts of the catchment. A significant ( $p$ <0.05) spatial variation of water quality parameters, except the hardness, Fluoride and $\mathrm{Ca}^{+2}$ among sites were observed to be associated with different land use categories. No significant $(\mathrm{p}>0.05)$ temporal variability in water quality parameters except Nitrite and hardness was detected. PCA and CA also indicated a strong association between the water quality variables and the land use types of the river basin. Urban impacts, land clearance in the catchment and sand mining activities of the river bed were found to be the most significant impacts to the water quality of the river and areas with forest cover having positive impact to the water quality. These findings emphasize the need of better catchment management approaches and remediation of urban impacts on river water quality.
\end{abstract}

Keywords: Land use; Multivariate Analysis; Nilwala River; Urbanization; Water quality 


\section{Introduction}

Despite being the life supporting systems of the earth aquatic ecosystems around the world are increasingly affected by various anthropogenic impacts (Alamet al. 2006). Human induced alterations to rivers and stream catchments have resulted in significant changes in stream health specifically water quality, structure and diversity of flora and fauna (Gage et al. 2004; Dudgeon et al. 2006). It has been observed that the conversion of forests to pastures and/or residential areas may influence water quality in rivers in many ways. Loss of terrestrial vegetation and an increased area of impervious surfaces can influence evapotranspiration and infiltration, and alter natural flow regimes (Changnon and Demissie 1996). These land use practices also increase the sediment inputs to streams and may alter substratum characteristics and channel morphology (Lake et al. 1985; Bunn et al. 1986). Altered catchment hydrology and land use can influence inputs of inorganic nutrients from terrestrial sources and may enhance in-stream primary production, resulting in change of the trophic structure of aquatic communities. Thus, catchment hydrology, as well as the availability of inorganic nutrients in streams is often related to processes that occur across the terrestrial landscape. Therefore, river water quality often reflects the conditions prevailing in the catchment and is an indication of the river health. As such, water quality monitoring programmes of rivers are essential in determination of pollution trends and pollution sources in order to initiate management strategies. However, processing complex, large data sets collected through monitoring programmes and determination of underlying trends of water quality variation are crucial for taking decisions related to pollution prevention and catchment management efforts. Multivariate analysis of data such as Principle Component Analysis (PCA) and Cluster Analysis (CA) are helpful in interpreting data and in determining driving factors for water quality variation which are difficult to interpret through general observations or through other studies. Application of multivariate techniques to analyse water quality data has been successfully applied in many situations (Pearce et al. 2013; Ndungu et al. 2014; Wang et al. 2014; Zeng and Arnold 2014).

The Nilwala River is the third largest in the southern province of Sri Lanka covering a distance of $72 \mathrm{~km}$. The River originates from the Sinharaja rain forest and flows largely through urban, agricultural and other areas of land use, reaches Matara town and joins the Indian Ocean at Thotamuna. The River catchment mainly consistsof agricultural lands and urban landscapes where most lands have been converted into commercial purposes. Rapid sand mining is also taking place in some parts of the river causing river bed to become lower than the mean sea level leading to salt water intrusion. The medium and small scale industries such as service stations, saw mills, tanneries as well as textile, batik, garment, food processing and painting industries are also located along the river in urban areas. Downstream areas of the river run through a developing commercial city where extensive area is undergoing rapid land use changes and deforestation. Despite the rapid changes of land use along its cause impacting the river health, the Nilwala River is the main supply source of drinking water to Matara town area and many rural and other urban communities 
along its cause (De Silva et al. 1998). It also provides water for agricultural practices and for industries located along the river catchment. Therefore, pollution of river water not only affects ecological health but also can have significant impacts on urban and rural communities who depend on river water. Therefore, the present study was carried out to estimate the spatial variation of water quality in the river and to estimate the association of land use practices on water quality variation using multivariate techniques. Findings of this study would be useful in implementing appropriate catchment management strategies for the Nilwala River basin.

\section{Study area}

\section{Materials and Methods}

The river catchment area represent approximately $1073 \mathrm{~km}^{2}$ and fall within the $5^{\circ} 55^{\prime}$ and $6^{\circ} 13^{\prime}$ and $80^{\circ} 25^{\prime}$ 'and $80^{\circ} 38^{\prime}$ (Figure 1). The course of Nilwala River consists of two distinct regions; the upstream part which has a steep longitudinal slope and the downstream lowlands which extend inland up to about $12 \mathrm{~km}$ from the coastline and has a gentle slope. Approximately 70 per cent of the Nilwala river basin is used for agricultural activities such as paddy, tea, coconut, cinnamon, citronella and rubber cultivations. The river also flows through urban areas which are densely populated and areas covered by forest patches. Specifically, lower part of the river runs through the developing commercial city of Matara, where extensive area is undergoing rapid land use changes.

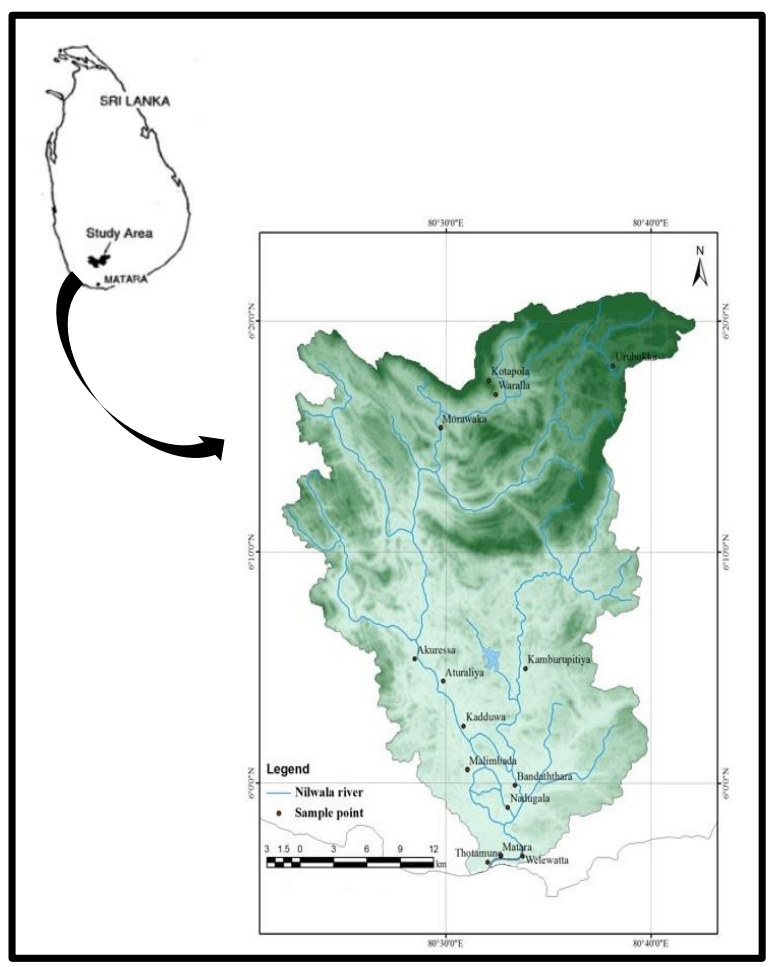

Figure 1. Sampling locations of the Nilwala River. 


\section{Sampling locations}

Water samples were collected from 16 locations of the lower reaches of the river in two week intervals from September 2010 to December 2010 (Figure 1). Duplicate samples were collected from each sampling location at a sampling event. The sampling locations and associated land uses are listed in the Table 1.

Table 1. Sampling locations and associated land use practices.

\begin{tabular}{ll}
\hline Sampling site & Main land use patterns \\
\hline Kotapola & Forest \\
Waralla & Forest; Agriculture \\
Morawaka & Forest area; Tea; Other vegetation \\
Berubewala Bridge & Forest reserve area \\
Urubokka & Land clearance and soil erosion is prominent \\
Akurassa & Agriculture area; Mainly paddy fields; Other vegetation \\
Kudduwa & Sand mining Area; Vehicle service centres \\
Kamburupitiya & Paddy fields; Rubber estates \\
Athuraliya & Agricultural area \\
Malimbada & Home gardens; Agriculture lands \\
Bandaththara & Sand mining Area \\
Nadugala & Marsh land \\
Wellatota & Area affected by soil erosion Forests are cleared \\
Welewatta & Urban area \\
Matara Town & Urban area; Food processing industries; Vehicle \\
& repairing and service centres; Densely populated area \\
Thotamuna & Marsh land; Urban area \\
\hline
\end{tabular}

Water quality parameter such as $\mathrm{pH}$, electrical conductivity, dissolved oxygen, Biochemical Oxygen Demand $\left(\mathrm{BOD}_{5}\right)$, turbidity, colour, total dissolved solids, total hardness, alkalinity, $\mathrm{NO}_{2}^{-}-\mathrm{N}, \mathrm{NO}_{3}{ }^{-}-\mathrm{N}, \mathrm{PO}_{4}{ }^{3-}-\mathrm{P}, \mathrm{SO}_{4}{ }^{3}$, total $\mathrm{Fe}, \mathrm{Ca}^{2+}, \mathrm{F}^{-}$and $\mathrm{Cl}^{-}$were evaluated in the sampling locations. The $\mathrm{pH}, \mathrm{EC}$, temperature, dissolved oxygen were measured in situ using a Portable Multiparameter (MULTI 1970i). Colour was estimated by visual comparison method using Nessalizer tubes. Turbidity was measured using a turbidity meter (HACH 2100Qis). For the analysis of other water quality parameters, water samples were collected to $1.5 \mathrm{~L}$ sampling bottles and transported to the laboratory under chilled condition.TDS was calculated using oven dry method, where $25 \mathrm{ml}$ sample was filtered using $0.45 \mu$ filter paper, filtrate was dried at $105^{\circ} \mathrm{C}$ and residue weight was taken. Biochemical oxygen demand $\left(\mathrm{BOD}_{5}\right)$ was estimated following the Winkler's method after incubating a water sample for 5 days. Total alkalinity was measured using titrimetric method. $\mathrm{NO}_{2}{ }^{-}-\mathrm{N}, \mathrm{NO}_{3}{ }^{-}-\mathrm{N}, \mathrm{PO}_{4}{ }^{3-}$ $-\mathrm{P}, \mathrm{SO}_{4}{ }^{3-}$, Total $\mathrm{Fe}, \mathrm{Ca}^{2+}, \mathrm{F}^{-}, \mathrm{Cl}^{-}$and hardness were measured at the laboratory using 
HACHDR5000 spectrophotometer. All analysis were conducted following APHA (2005) procedures.

\section{Data analysis}

Two-way ANOVA was conducted considering land use type and time as main factors, to analyze variation of water quality parameters in sites associated with different land use categories and temporal variation of water quality parameters. Data were checked for normality and for homogeneity of variance before the analysis. Turkey's post-hoc test was conducted for pair-wise comparisons. SPSS Statistical software was used for the analysis of data. Principal component analysis (PCA) and cluster analysis (CA) were conducted to identify underlying patterns of variation of water quality in relation to land use practices. These analysis were conducted using PRIMER-5 software. In PCA, the eigen values of the principal components are a measure of their associated variances (Mellinger 1987; Meglen 1992; Wenning and Erickson 1994).Correlation of principal components and original variables are given by loadings. Cluster analysis uncovers intrinsic structure or underlying behaviour of a dataset without making a priori assumptions about the data. It further classifies objects of the system into categories (clusters) based on their similarity. In the present study, the water quality data were used as input variables for PCA. Since water quality parameters had different magnitudes and scales of measurements, the data were standardized through double-square root transformation to produce a normal distribution of all variables (Davis 1973).From the standardized correlation matrix of the data, the initial factor solutions were extracted by the principal components and then a number of PCs were selected according to their eigen values. Component loading (correlation coefficients), which measure the degree of closeness between the variables and the PCs were also estimated. The most significant variables in the components represented by high loadings were taken into consideration in evaluating the components (Mazlumet al.1999).

\section{Results}

\section{Physico chemical parameters}

All physical and chemical water quality parameters, except total hardness, $\mathrm{F}^{-}$and $\mathrm{Ca}^{+2}$ detected in sites associated with different land use categories indicated significant differences $(\mathrm{p}<0.05)$ (Table 2). Except for the total hardness, all other water quality variables did not indicate temporal variation during the study period.

During the study period, average $\mathrm{pH}$ recorded in sites ranged between 5.8 and 7.3. The highest average value was recorded at Wellatota where land clearing activities are taking place and lowest values were associated with urban areas such asin Thotamuna and in Matara town, where the $\mathrm{pH}$ were $<5$ during some months (Figure 2). Generally urban sites had relatively low $\mathrm{pH}$ values, in comparison to the other sites. Average water color of the sites varied between $34.3 \mathrm{HU}$ at Kotapola a forested area to $200 \mathrm{HU}$ at more urbanized Matara town area (Figure 2). 
Table 2.Results of two- way ANOVA on water quality analysis.

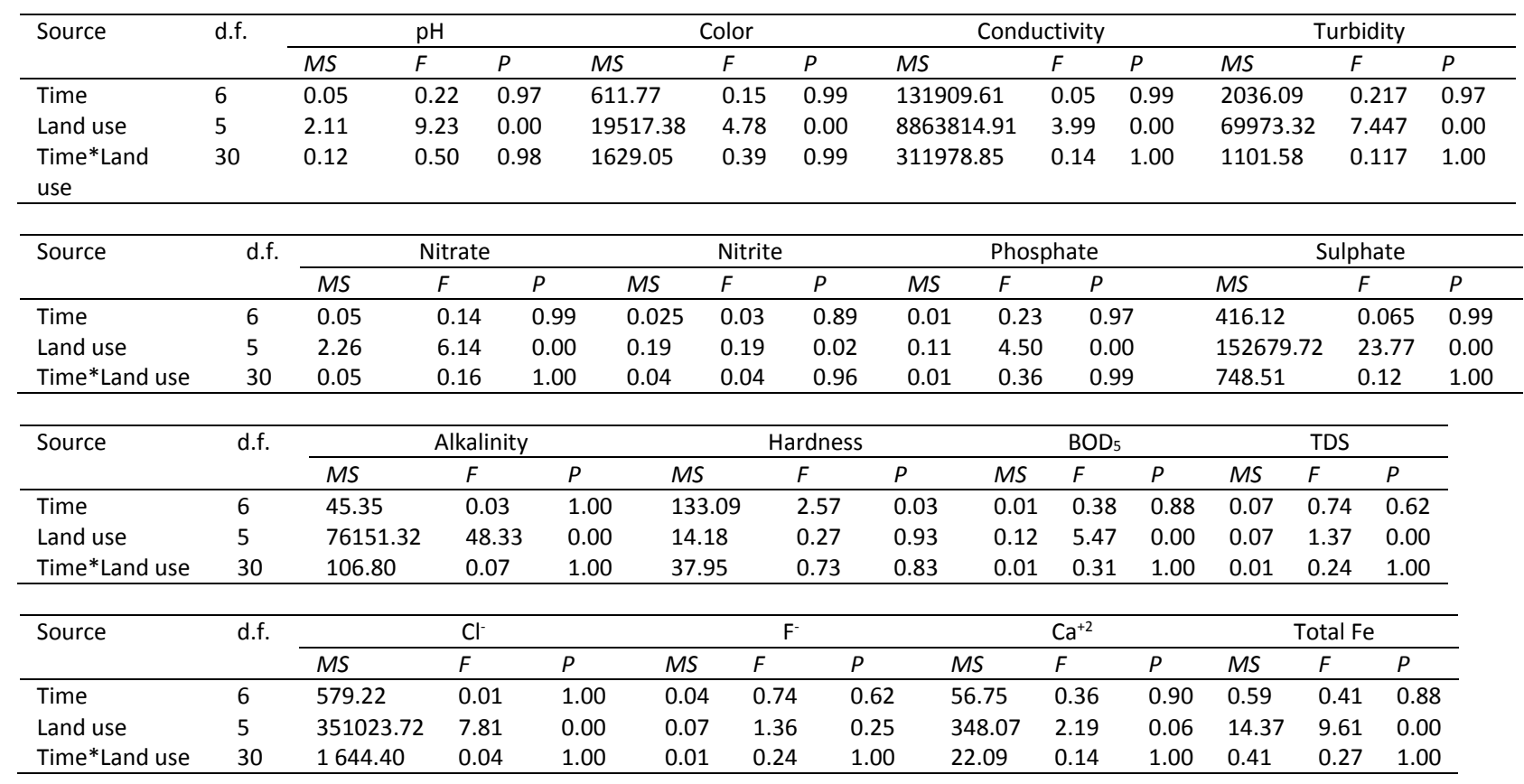


Generally, urban sites and sites associated with cleared lands were having higher water colour. Average turbidity values of sites ranged between $4.8 \mathrm{mgl}^{-1}$ at Athuraliya an agricultural area to $354 \mathrm{mg}^{-1}$ at Welewatta an urban area. Lower turbidity values (6.15 NTU and 5.23 NTU) were also recorded at Kotapola a forested area in Kuddawa and high values (149.86NTU) in urbanized Matara town area. On average higher turbidity values were associated with urban areas (Figure 2). Average conductivity values recorded ranged from $57.9 \mu \mathrm{Scm}^{-1}$ to $5,057 \mu \mathrm{Scm}^{-1}$ where higher values were recorded at Matara town area, Thotamunabridge, Bandaththara and at Kudawasites and lower values were recorded in Kotapola, Warallaand Athuraliya sites. Generally urban and cleared areas were having higher conductivity values (Figure 2). Average TDS values ranged between 42.9 to $3,488.7 \mathrm{mg} \mathrm{l}^{-1}$; the highest value was recorded in Matara town area and the lowest value was recorded in Morawaka area. TDS values recorded also indicated similar trend to the variation to conductivity where higher values were associated with urban sites and cleared sites (Figure 2). Alkalinity values ranged between 19.9 and $177 \mathrm{mgl}^{-1}$ in sites. The highest alkalinity values were recorded in Athuraliya and Malimbada areas while the lowest value was recorded in Waralla site. Generally, higher alkalinity values were associated with sites associated with agricultural areas (Figure 3). $\mathrm{BOD}_{5}$ values of the sites ranged from $0.97 \mathrm{mgl}^{-}$ ${ }^{1}$ recorded at Kotapola area to $1.39 \mathrm{mgl}^{-1}$ recorded in Matera town area. Higher BOD 5 values were recorded in sites associated with urban areas (Figure 2). The total hardness varied from $21.7 \mathrm{mgl}^{-1}$ to $32.5 \mathrm{mgl}^{-1}$ among different sites, and however, these were not significantly different among sites associated with different land use categories (Figure 3).

\section{Nutrients}

The nutrients analysed in the sites include $\mathrm{NO}_{2}{ }^{-} \mathrm{N}, \mathrm{NO}_{3}{ }^{-}-\mathrm{N}, \mathrm{PO}_{4}{ }^{3-}-\mathrm{P}$ and $\mathrm{SO}_{4}{ }^{3-}$ and these were significantly $(\mathrm{p}<0.05)$ different in sites associated with different landuse categories (Table 2). Average $\mathrm{NO}_{3}^{-}-\mathrm{N}$ levels in the sampling sites ranged between 0.001 and $1.86 \mathrm{mg} \mathrm{1}^{-1}$. Lower $\mathrm{NO}_{3}-\mathrm{N}$ levels were recorded in Waralla and Malimbada area and the higher values in urban areas such as Thotamunabridge and Matara town area (Figure 3). Lower $\mathrm{NO}_{2}^{-}-\mathrm{N}$ levels were recorded in Kotapala, Bandaththara, Nadugala, Akurassa and Kudawa area. Higher $\mathrm{NO}_{2}^{-}-\mathrm{N}$ levels were recorded in urban sites such as Welewatta and Thotamuna area. $\mathrm{PO}_{4}{ }^{3-} \mathrm{P}$ levels in the sampling sites ranged between 0.18 and $0.68 \mathrm{mgl}^{-1}$ and lower values were recorded in forested areas such as Waralla and Morawaka and higher values in urbanized Thotamuna and Matara town area. Relatively higher $\mathrm{PO}_{4}{ }^{3-} \mathrm{P}$ levels were also recorded in Agricultural areas as well. $\mathrm{SO}_{4}{ }^{3-}$ ranged between 4.1 to $403.9 \mathrm{mgl}^{-1}$ among sampling sites and higher values were recorded in Matara town, Welewatta and Kamburupitiya and lower values in Kudawa and forested areas (Figure 3). 

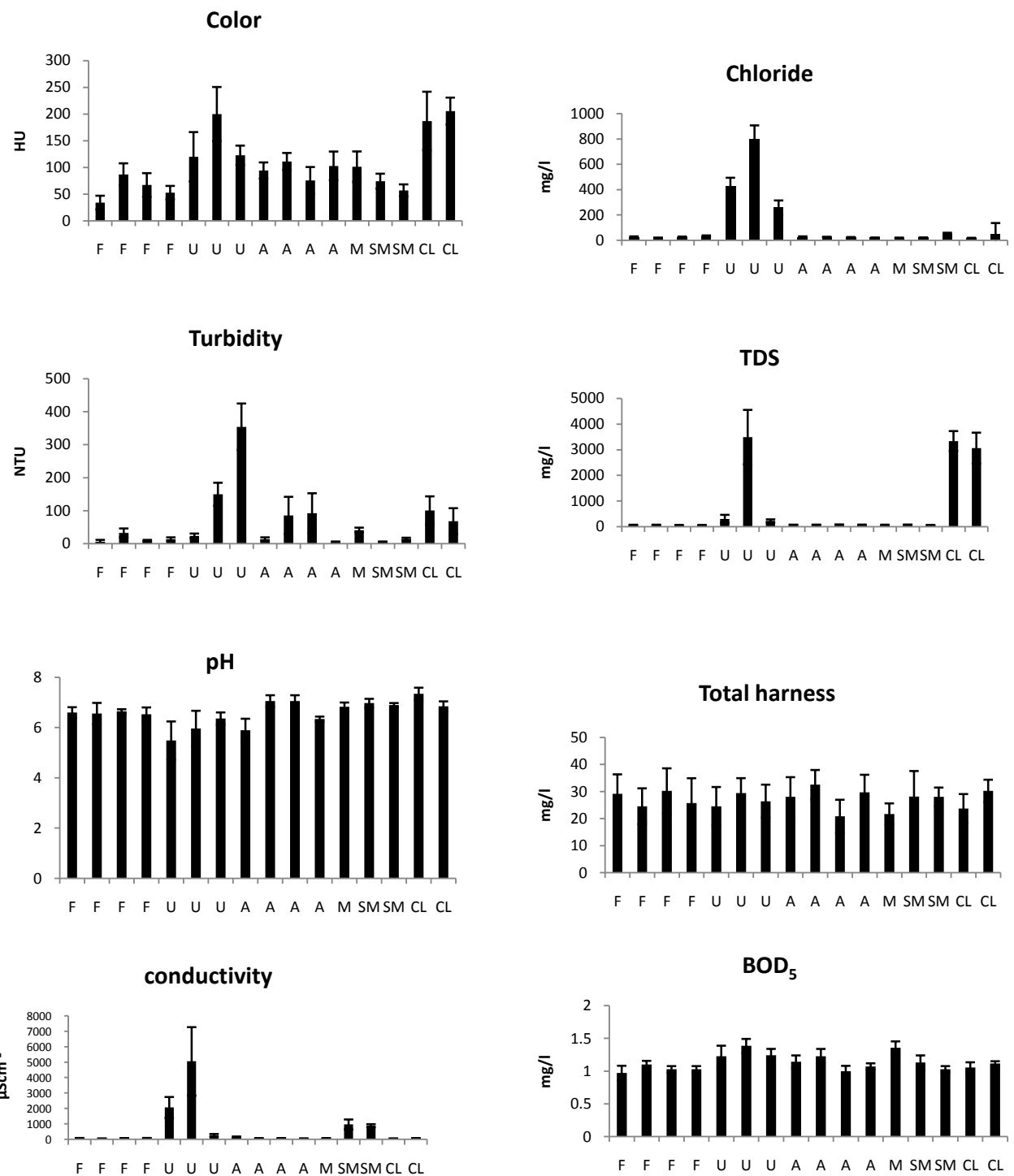

Figure 2. Water quality variables associated with different land use practices (F- Forest; U- Urban; AAgriculture; M- Marsh; SM- Sand mining; CL- Cleared land) 

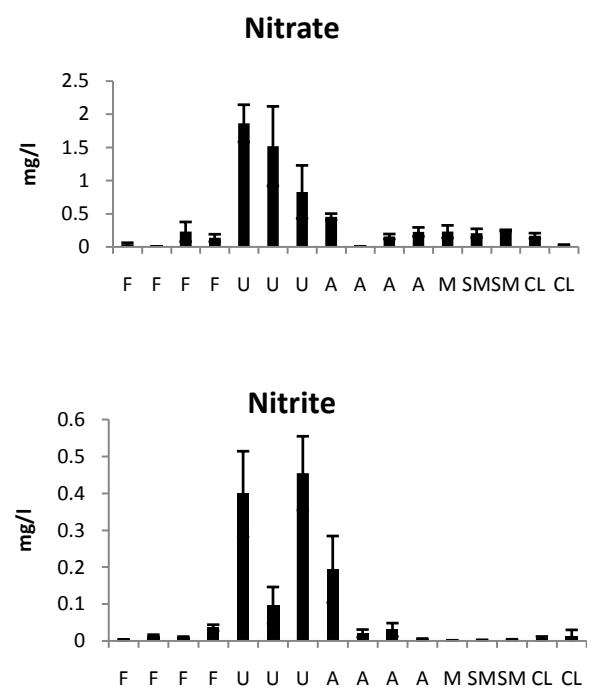

Phosphate

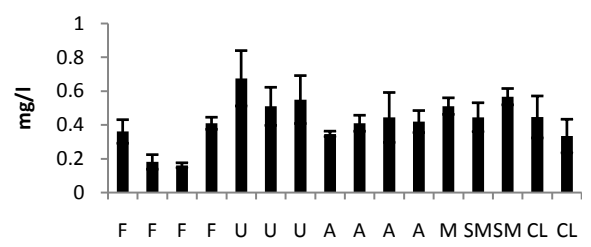

Sulphate

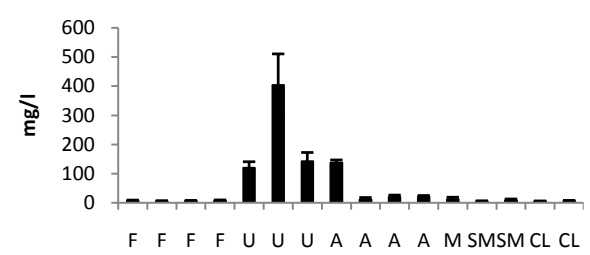

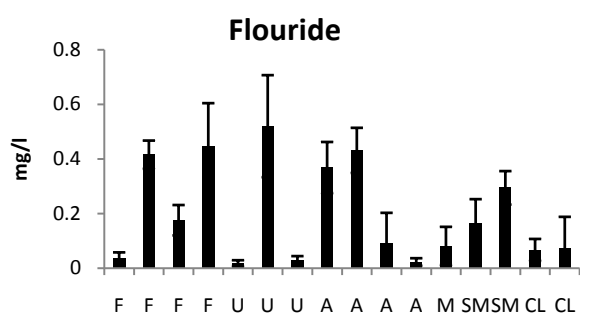

$\mathrm{Ca}$

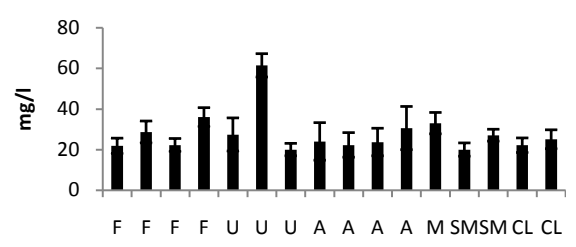

Total Iron

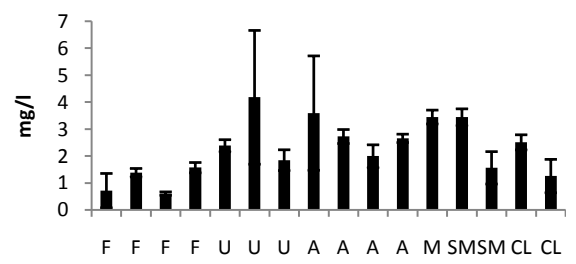

Alkalinity

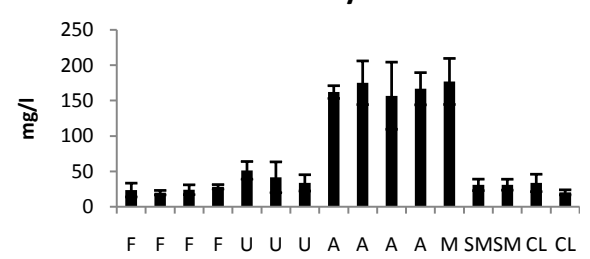

Figure 3. Water quality variables associated with different land use practices (F- Forest; U- Urban; AAgriculture; M- Marsh; SM- Sand mining; CL- Cleared land)

\section{Main ions}

Main ions recorded in the sites include Total $\mathrm{Fe}, \mathrm{Ca}^{2+}, \mathrm{F}^{-}$and $\mathrm{Cl}^{-}$(Table 2). Except for the $\mathrm{F}^{-}$and $\mathrm{Ca}^{2+}$, all other ions were significant different $(\mathrm{p}<0.05)$ among sites associated with different land use categories. Fluoride levels ranged between 0.02- 
$0.52 \mathrm{mgl}^{-1}$ among sampling sites, however these variations were not significantly different among main land use categories. The highest F-level was recorded in Matera town area. Chloride levels in the sites ranged between 17.1 and $799 \mathrm{mg} \mathrm{l}^{-1}$ whereas the highest values were recorded in Matara town area. Calcium levels recorded in sites ranged between $21.9 \mathrm{mg} \mathrm{l}^{-1}$ recorded at Kotapola and $61.4 \mathrm{mgl}^{-1}$ recorded in Matara town area. Total Fe concentration ranges between $0.61 \mathrm{mg} \mathrm{l}^{-1}$ recorded in Morawaka to $4.2 \mathrm{mg} \mathrm{l}^{-1}$ recorded in Matara town area (Figure 3).

\section{Principal component analysis}

Analysis of the data using principal component analysis (PCA) and cluster analysis (CA) enabled the identification of the sources of pollutants into the river based on the level of association of the variables. PCA performed on correlation matrix of means of water quality parameters recorded in the sites. Five principal components represented $85 \%$ of the total variation of the data set. The actual eigen values and \% cumulative variables are shown in Table 3 .

Table 3. Principal components, their eigen values, $\%$ variations and $\%$ cumulative variations.

\begin{tabular}{cccc}
\hline PC & Eigen values & \%variation & $\begin{array}{c}\text { Cumulative } \\
\text { \% variation }\end{array}$ \\
\hline 1 & 6.9 & 42.8 & 42.8 \\
2 & 2.3 & 14.4 & 57.2 \\
3 & 1.9 & 11.6 & 68.8 \\
4 & 1.5 & 9.6 & 78.4 \\
5 & 1.1 & 6.7 & 85.1 \\
\hline
\end{tabular}

The PCA bi-plot of water quality variables for all sample sites is given in Figure 4.The first PC accounted for $42 \%$ of the variation of the water quality data and the second component accounted for $14 \%$. Both $1^{\text {st }}$ and $2^{\text {nd }} P C$ accounted for $56 \%$ of the total variation. A clear separation of sites in the urban, agriculture and the forested landscapes were observed along the $1^{\text {st }}$ axis. Vector loading to principal component axis indicated that nutrients (nitrate, sulphate), BOD, TDS and EC are highly correlated with $1^{\text {st }}$ axis suggesting the main variables driving the separation of sites along $1^{\text {st }}$ axis. Nutrients $\left(\mathrm{NO}_{2}{ }^{-}-\mathrm{N}, \mathrm{PO}_{4}{ }^{3-}-\mathrm{P}\right)$, dissolved ions $\left(\mathrm{F}^{-}\right)$and hardness are mainly responsible for the separation of sites along $2^{\text {nd }}$ axis. The separation of sites along second axis is possibly due to the variation of these parameters among sites. Colour, alkalinity, TDS, total Fe are highly associated with the $3^{\text {rd }}$ axis. 


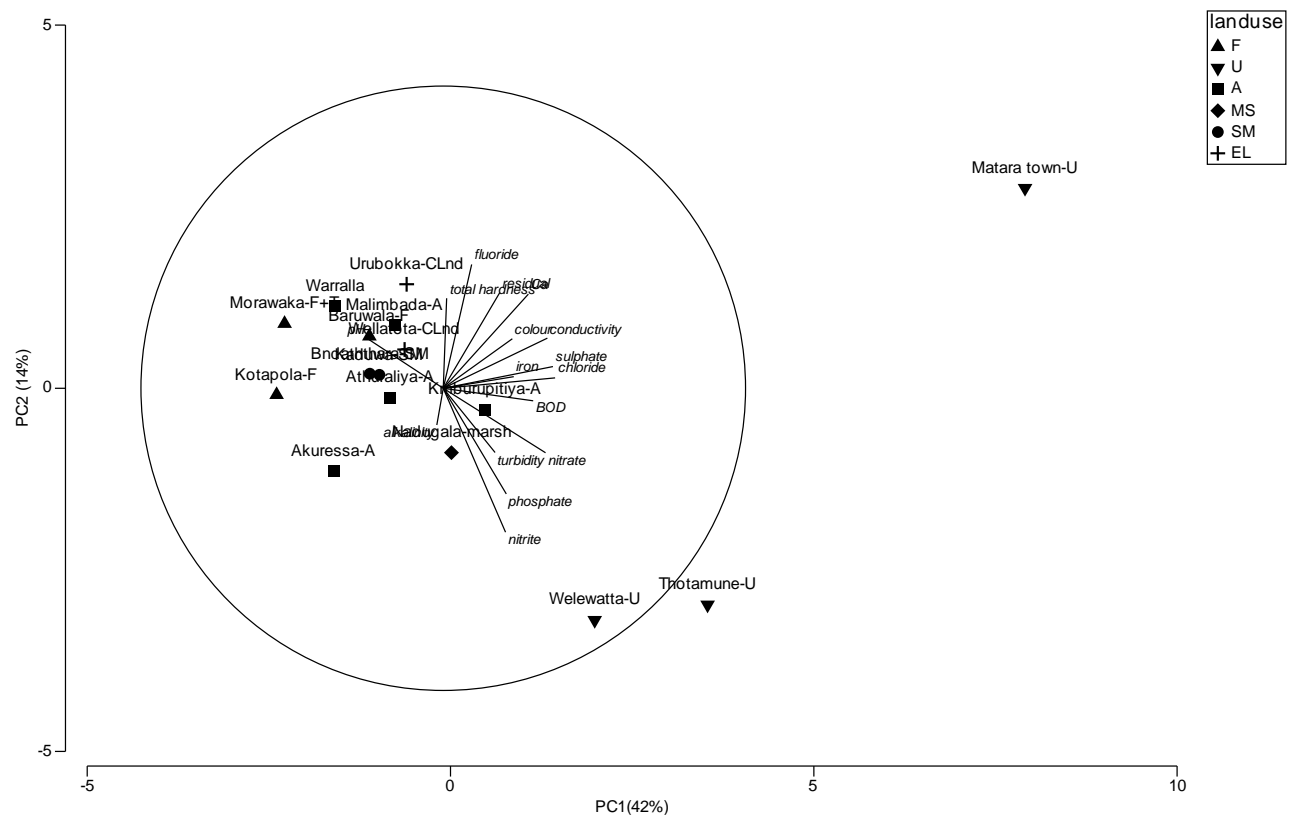

Figure 4. PCA bi-plot of water quality parameters and land use categories. U-urban; A-agriculture; SM- sand mining; MS-marsh land; F- forest; CLD-cleared land.

\section{Cluster Analysis}

The results of the cluster analysis also indicate a similar pattern of variation among sites as indicated by PCA (Fig.5). Euclidean distances displayed in the cluster diagram (which represent the dissimilarity among clusters) show a clear separation of sites of urban, cleared lands and sand mining areas of river from forested and agricultural sites. Agricultural and forested areas are also clustered separately. Cleared land sites were clustered separately from urban and sand mining areas.

\section{Discussion}

The observation of physical and chemical water quality parameters in selected locations in Nilwala River indicated significant $(\mathrm{p}<0.05)$ spatial variation among sites associated with different land use categories. These variations can be clearly linked to the land use practices associated with catchments of sampling sites. However, hardness, $\mathrm{F}$ - and $\mathrm{Ca}^{+2}$ detected in sites associated with different land use categories indicated no significant differences $(\mathrm{p}>0.05)$. Similarly, except for the total hardness, all other water quality variables did not show significant temporal variation. The sampling was done within four month time period, in two week intervals, during which no marked seasonal variation existed, may have attributed to such a pattern of water quality variables over time. 


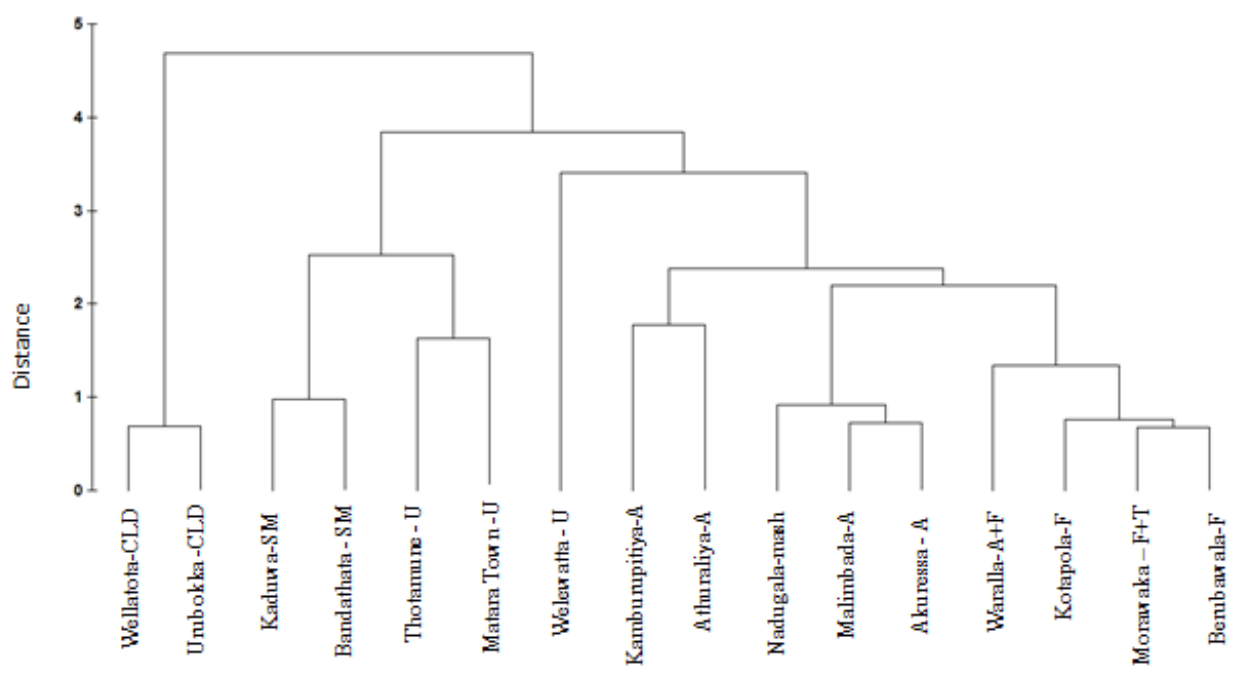

Figure 5. Dendrogramof sampling sites based on water quality data clustering on a matrix of Euclidean distances. Main land uses: A- Agricultural lands; SM- Sand mining areas: F- Forest; CLD - Cleared lands; U - Urban areas

PCA also indicated a similar trend to the results of ANOVA in which a separation of urban, agriculture and forested areas attributing to the variation of nutrients (nitrate and sulphate), $\mathrm{BOD}_{5}$, TDS and EC. Urban sites were well separated from other sites indicating significant urban impacts on water quality.

$\mathrm{pH}$ of the sampling locations showed slight variation among the sites except for the Kamburupitiya, Thotamuna and Mathara town sites, where $\mathrm{pH}$ values lower than 5.5 were recorded. The $\mathrm{pH}$ range suitable for the existence of most biological life is quite narrow and critical, and is typically 6-9 (Tchobanoglous et al. 2003). However, $\mathrm{pH}$ recorded in those sites were even below these limits and also exceeded the limits of proposed ambient water quality standards for inland waters for fish and aquatic life, drinking water with conventional treatment, irrigation purposes according to CEA (2001) and according to WHO guidelines for drinking water quality (WHO 2004). Kamburupitiya site is within an agricultural area where rice and rubber cultivations are abundant. Thotamuna and Matara town area are urban areas. These two areas are mostly covered with marshy lands. It has been reported that lower floodplain soils in the Nilwala River contain acid sulphate soils (Fernanado and Suranganee 2009). Possibly the acidic soils in the marshy areas and acidic effluents coming with urban runoff (Osibanjo et al. 2011) may have contributed to the lower $\mathrm{pH}$ values recorded in these sites.

Significant differences $(p<0.05)$ in turbidity were recorded among sites associated with different land use categories. Very low turbidity values were reported in sites with forest patches and higher values were associated with urban areas. As stated by Izonfuo and Bariweni (2001), non-treated waste loads from the urban areas and soil particles brought by surface runoff of the agricultural areas may have 
contributed to the higher turbidity values recorded in urban (and some agricultural sites such as Akurassa and Malimbada areas. Similarly at Wallatota site, where land clearing activities are taking place, higher turbidity value was recorded. The ground cover that intercepts the energy of rain drops, retard the speed of surface water flow and enhance the surface water infiltration (Elkaduwa and Sakthivadivel 1998). It is possible that soil erosion due to land cover clearing activities at this site may have contributed to higher input of soil particles to the river leading to higher turbidity value in river water.

TDS value is an indication of the total dissolved ions in water and is important parameter when deciding suitability of water for irrigation purposes (Tchobanoglous et al. 2003). EC is also a measure of the ions present in water with a positive correlation. It is also in effect a surrogate for TDS. Significantly higher TDS values were recorded in sites associated with urban and cleared lands. In the present study, TDS values recorded in Matara town area, Urubokka and Wellatota areas exceeded the limits of proposed ambient water quality standards for inland waters for irrigation purposes (CEA 2001). Urubokka and Wellatota are areas where much of the lands in the catchment have been cleared and therefore soil erosion has become prominent. It is possible that salts dissolved with eroded soils may have contributed to high TDS values recorded in these sites. PCA indicated that ions such as total Fe, $\mathrm{Ca}^{+2}, \mathrm{~F}^{-}$and $\mathrm{Cl}^{-}$and $\mathrm{SO}_{4}{ }^{3-}$ are responsible for the increased TDS values in that site. Higher conductivity values which also exceeded the proposed ambient water quality standards for inland waters for irrigation purposes (CEA 2001) were recorded in sand mining areas, and in urban areas such as Thotamuna and Matara town sites. It is possible that disturbance of river sediments due to sand mining and closeness of the sites to sea mouth might have contributed to the higher conductivity values recorded in those sites. Similarly, intense sand mining activities practiced in the river channel has been contributed to the lowering of river bed below the mean sea level in many parts of the river. This may have contributed to the sea water intrusion through the river to inland areas giving higher conductivity values in many parts of the lower reaches of the river. The river water is widely used for drinking purposes and agricultural activities by the communities residing along river. It is possible that higher TDS levels and conductivity in water can adversely affect the water supply schemes to urban and rural communities from the river. Similarly, the use of river water for agricultural practices over the time can also lead to issues such as salinization of soils of the agricultural lands.

Higher sulphate levels were recorded in the water at the Matera town site is an indication of contamination of river water with urban waste (Osibanjo et al. 2011). In addition, acid sulphate soils prevailing in the area may have also contributed to the higher sulphate levels in the water (Fernanado and Suranganee2009).

Higher values for alkalinity were recorded in Malimbada and Nadugala which are agricultural areas and lower values were recorded in areas with forest cover (Table 2). Alkalinity is a measure of the acid neutralizing capacity of water. Alkalinity of river water is also governed by the geological set up of the river catchment. The main sources of natural alkalinity to water are the rocks, which contain carbonate, bicarbonate and hydroxide compounds (Aziz-ur-Rahman and Chughtai 2014).Similarly borates, silicates, and phosphates may also contribute to alkalinity of 
the water (Aziz-ur-Rahman and Chughtai 2014).It is also possible that fertilizer application in agricultural areas such as use of dolamite in tea estates may have contributed to higher alkalinity levels when they enter the river water. However, soils in forested areas are mostly acidic and may have contributed to lower alkalinity values in the water.

$\mathrm{BOD}_{5}$ is an indication of the organic pollution of water (Tchobanoglous et al. 2003). In the present study, high $\mathrm{BOD}_{5}$ values were associated with the urban areas and low values were associated with forested sites. However, $\mathrm{BOD}_{5}$ values did not exceed the limits of proposed ambient water quality standards of fish and wildlife and irrigation and drinking water in inland water bodies of Sri Lanka (CEA 2001). The relatively higher $\mathrm{BOD}_{5}$ values recorded in urban sites can be attributed to the urban waste and runoff coming from urban areas. Illegal diversion of waste water from urban centres to the river may have contributed to this problem.

$\mathrm{NO}_{2}{ }^{-}-\mathrm{N}, \mathrm{NO}_{3}{ }^{-}-\mathrm{N}, \mathrm{PO}_{4}{ }^{3-}-\mathrm{P}$ and $\mathrm{SO}_{4}{ }^{3-}$ are the main nutrient ions monitored in this study. According to the results of ANOVA, PCA and CA there is a clear separation of sites based on the nutrient levels. It was evident from the analysis that urban sites are closely associated with nutrient enrichment. Similarly, excess fertilizer which is contaminating the river from upstream land use practices such as agricultural activities may have also contributed to this situation. Several researchers have reported the impact of agriculture on the quality of irrigation and potable water in Sri Lanka (Amarasekara 1992; Bandara et al. 2008; Bandara et al. 2011). Application of excessive quantities of nitrates and phosphates are associated with eutrophication of reservoirs and heavy nitrate levels in reservoirs and ground water in Sri Lanka (Weeraratne and Wimalawansa 2015). However, results of the PCA analysis of the present study, indicated, less marked separation of agricultural and forested sites based on the nutrient levels. Possibly the different ratios of forest to agricultural lands in the upper catchments may have contributed to the less marked separation of these sites with regard to the nutrient concentration. Application of phosphate containing fertilizer and their subsequent removal from farm lands contribute significantly to the contamination of waterways with phosphates. However, many workers previously reported that in the absence of erosion little phosphorous could reach the surrounding water (Loher 1974; Dillon and Kirchner 1975; Heise 1984). Therefore, it is possible that extent of soil erosion prevention practices adopted in agricultural lands in the present study area may have an impact on contamination of water with fertilizers with phosphates. Experiments have shown that in well-managed tea crops with $100 \%$ ground cover with surface runoff, soil erosion conditions are closer to those of a natural forest (Krishnarajah 1985).Similarly, rice fields also retain much of the fertilizer applied to them. It is possible that such agricultural practices in areas closer to study locations may have contributed to lower erosion rates of soils and fertilizer leaching from crop lands. Present results suggest that urban runoff is the main factor contributing to $\mathrm{PO}_{4}{ }^{3-} \mathrm{P}$ to river water. Wellatota and Thotamuna areas are highly associated with higher $\mathrm{PO}_{4}{ }^{3-} \mathrm{P}$ levels. These levels recorded in urban sites also exceeded the limits of proposes ambient water quality standards of fish and wildlife, irrigation and drinking water by CEA (2001). Matara town area is also highly associated with $\mathrm{SO}_{4}{ }^{3-}$ levels, suggesting severe pollution trends due to urban runoff. 
Also, there is separation of urban sites based on the main ion concentrations. Generally, urban areas are located close to the sea mouth of the river. Intrusion of sea water may have contributed to the higher levels of ions and conductivity values recorded in these sites than those of other sites. Sand mining activities, which have contributed to lowering of river bed below the sea level may have particularly contributed to sea water intrusion upstream and subsequent rise in major ion levels in river water.

The present study shows that PCA and CA could be successfully used to separate river sites with different land use influences based on water quality. Similar approaches have been adopted successfully by many authors to demonstrate water quality (Ndungu et al. 2014; Sheela et al. 2012). Ndunguet et al. (2014) investigated the water quality status and pollution sources in Lake Naivasha, Kenya using multivariate techniques and could successfully identify the separate regions in the lake having water quality differences and pollution. Sheela et al. (2012) also used multivariate approaches for water quality analysis in Akkulam-Veli Lake in India and found the sources of pollutants in relation to seasonal rainfall events. Based on the observations of present study, it is evident that urban impacts, land clearing and sand mining activities have a highly significant impact on river water quality in Nilwala River. However, water quality data can vary temporally and spatially depending on the seasonal, geographical and anthropogenic impacts. The present study was conducted during four-month duration and this time duration was not sufficient to capture the temporal variation of water quality in sampling sites which might be brought about by seasonal impacts. Therefore, it is important to continue water quality monitoring programmes to cover such spatial and temporal dimensions and to adopt appropriate analysis in order to understand the underlying trends.

The investigated water quality parameters clearly showed that the land use practices in the catchments can influence the water quality in Nilwala River. Urbanization followed by land clearing and agricultural practices had a great influence on water quality through the input of waste from urban areas. However, the intensity of the land-use impacts of water quality may also depend on the spatial scales of land use practices in the catchments (Sponeller et al. 2001). Therefore, it is important to quantify the different land uses in the catchment for better understanding of land use influences. However, present information is fundamental in setting guidelines for effective catchment management particularly in the control of river pollution, when formulating policies regarding the urban waste and runoff management as well as agricultural land management in river catchments.

\section{References}

Alam K., J.Rolfe \& P. Donaghy 2006. Economic and social impact assessment of water quality improvement. Australasian Journal of Regional Studies 12(1): $85-102$.

Amarasekera N. 1992. Environmental consequences of major irrigation development in Sri Lanka: A preliminary assessment. Water International 17(2): 88-97.

APHA 2005. Standard Methods, 21st Edition. American Public Health Association: Washington DC. 1200p. 
Aziz-ur-Rahman \& M.O. Chughtai 2014. Regional interpretation of river Indus water quality data using regression model.African Journal of Environmental Science and Technology 8(1): 86-90. doi: $10.5897 / A J E S T 2013.1610$

Bandara J.M.R.S., D.M.A.N. Senevirathna, D.M.R.S.B. Dasanayake, V. Herath, J.M.R.P. Bandara, T. Abeysekara\& K.H.Rajapaksha 2008. Chronic renal failure among farm families in cascade irrigation systems in Sri Lanka associated with elevated dietary cadmium levels in rice and freshwater fish (Tilapia). Environmental Geochemistry and Health. 30 (5): 465-478. doi: 10.1007/s10653-007-9129-6

Bandara J.M.R.S., H.V.P. Wijewardena, Y.M.A.Y. Bandara, R.G.P.T. Jayasooriya \& K.H. Rajapaksha 2011. Pollution of River Mahaweli and farmlands under irrigation by cadmium from agricultural inputs leading to a chronic renal failure epidemic among farmers in NCP, Sri Lanka. Environmental Geochemistry and Health.33(5): 439-453. doi: 10.1007/s 10653-010-9344-4

Bunn S.E.1986. Spatial and temporal variation in the macroinvertebrate fauna of streams ofthe northern jarrah forest, Western Australia: functional organisation. Freshwater Biology 16: 621-632. doi: 10.1111/j.13652427.1986.tb01005.x

Changnon S.A. \& M. Demissie 1996. Detection of changes in streamflow and floods resulting from climate fluctuations and land use-drainage changes. Climatic Change 32: 411-421. doi: 10.1007/BF00140354

CEA 2001. Proposed ambient water quality standards for inland waters of Sri Lanka, Environment Action 1 Project (funded by ADB), Central Environmental Authority, Colombo.

Davis J.C.1973. Statistics and Data Analysis in Geology. John Wiley and Sons, Inc., New York. 550p.

De Silva M.P., R.Karunatileka\& W.H.P. Thiemann 1998. Study of some physicochemical properties of Nilwala River waters in Southern Sri Lanka with special reference to effluents resulting from anthropogenic activities. Journal of Environmental Science and Health-Part A Environmental Science and Engineering 23(4): 381-398. doi: 10.1080/10934528809375419

Dillon P.J.\&W.B. Kirchner1975. The effect of geology and land use on the export of phosphorus from watersheds. Water Research 9: 135-147. doi: 10.1016/0043-1354(75)90002-0

Dudgeon D., A.H. Arthington, M.O. Gessner, Z.-I. Kawabata, D.J. Knowler, C. Lévêque, R.J. Naiman, A.-H. Prieur-Richard, D. Soto, M.L.J. Stiassny\& C.A. Sullivan2006. Freshwater biodiversity: importance, threats, status and conservation challenges. Biological Reviews 81: 163-182. doi: http://dx.doi.org/10.1017/S1464793105006950

Elkaduwa W.K.B. \& R.Sakthivadivel1998. Use of historical data as a decision support tool in watershed management: a case study of the upper Nilwala basin in Sri Lanka. Research Report 26, International Water Management Institute, Colombo. 32p. 
Fernando G.W.A.R. \& R.K.N. Suranganee 2009. Development of acid sulphate soils in Nilwala flood protection area, Matara, Sri Lanka. Journal of Geological Society of Sri Lanka 13: 71-82.

Gage M.S., A. Spivak\& C.J. Paradire 2004. Effect of land use and disturbance on benthic insects in headwater streams draining small watershed north of Charlotte, NC. Southeastern Naturalist 3(2): 345-358. doi: http://dx.doi.org/10.1656/1528-7092(2004)003[0345:EOLUAD]2.0.CO;2

Heise P. 1984. Gudena. pp. 25-50. In:B.A. Witton (ed.), Ecology of European Rivers. Blackwell Science, Oxford.

Izonfuo L.W.A. \& A.P. Bariweni 2001.The Effect of urban runoff water and human activities on some physico- chemical parameters of the Epie Creek in the Niger delta. Journal of Applied Sciences and Environmental Management 5(1): 47-55. doi: http://dx.doi.org/10.4314/jasem.v5i1.54941

Krishnarajah P. 1985. Soil erosion control measures for tea land in Sri Lanka. Sri Lanka Journal of Tea Science 54(2): 91-100.

Lake P.S., L.A. Barmuta, A.J. Boulton, I.C. Campbell \&R.M St Clair1985. Australian streams and Northern Hemisphere stream ecology: Comparisons and problems. Proceedings of the Ecological Society of Australia14: 61-82.

Loher R.C. 1974. Characteristics and comparative magnitude of non-point sources. Journal of Water Pollution Control Federation. 46: 1849-1856.

Meglen R.R.1992. Examining large databases: a chemometricapproachusing principal component analysis. Marine Chemistry 39(1-3): 217-237. doi: 10.1016/0304-4203(92)90103-H

Mellinger M. 1987. Multivariate data analysis: Its methods. Chemometricsand Intelligent Laboratory Systems 2(1-3): 29-36. doi: 10.1016/01697439(87)80083-7

Mazlum N.,A. Ozer\& S. Mazlum1999. Interpretation of water quality data by principal components analysis. Journal of Engineering and Environmental Science 23:19-26.

Ndungu J., D.C.M. Augustijn analysis of water quality in Lake Naivasha, Kenya. Marine and Freshwater Research 66(2): 177-186. doi: 10.1071/MF14031

Osibanjo O., A.P. Daso \& A.M.Gbadebo2011. The impact of industries on surface water quality of River Ona and River Alaro in Oluyole Industrial Estate, Ibadan, Nigeria. African Journal of Biotechnology 10(4):696- 702. doi: 10.5897/AJB10.1065

Pearce A.R., D.M. Rizzo, M.C. Watzin \& G.K. Druschel2013.Unraveling associations between cyanobacteria blooms and in lake environmental conditions in Missisquoi Bay, Lake Champlain, USA, using a modified selforganizing map. Environmental Science and Technology 47(24): 1426714274. doi: 10.1021/es403490g

Sheela A.M., J. Letha, S. Joseph, M. Chacko, S.P. Sanalkumar\& J. Thomas2012. Water quality assessment of a tropical coastal lake system using multivariate cluster, principal component and factor analysis. Lakes and Reservoirs: Research and Management 17(2):143-159. doi: 10.1111/j.14401770.2012.00506.x 
Sponseller R.A., E.F. Benfield \& H.M. Valett 2008. Relationships between land use, spatial scale and stream macroinvertebrate communities. Freshwater Biology 46 (10): 1409-1424. doi: 10.1046/j.1365-2427.2001.00758.x

Tchobanoglous G., F.I. Burton \& H.D. Stensel 2003.Wastewater Engineering: Treatment and Reuse.Forth Edition. Metcalf \& Eddie, Inc. McGraw Hill, New York.

Wang Y.-B., Liu, C.-W., Liao, P.-Y., \& J.J. Lee2014. Spatial pattern assessment of river water quality: implications of reducing the number of monitoring stations and chemical parameters. Environmental Monitoring and Assessment 186(3): 1781-1792. doi: 10.1007/s10661-013-3492-9

Weeraratne S. \& S.J. Wimalawansa 2015. A major irrigation project (accelerated Mahaweli programme) and the chronic kidney disease of multifactorial origin in Sri Lanka. International Journal of Environmental and Agriculture Research 1(6): 16-27.

Wenning R. J., \& G. A. Erickson1994. Interpretation and analysis ofcomplex environmental data using chemometric methods. Trendsin Analytical Chemistry 13(10): 446-457. doi: 10.1016/0165-9936(94)85026-7

WHO 2004. Guidelines for Drinking Water Quality, 3rd Edition. World Health Organization, Geneva. 142p.

Zeng T. \& W.A. Arnold 2014. Clustering chlorine reactivity of haloacetic acid precursors in inland lakes. Environmental Science and Technology48(1): 139-148. doi: 10.1021/es403766n 